\title{
Sustainability reports from the food industry: case studies from Europe and Latin America
}

\author{
A. Hoeltl ${ }^{1}$, R. Brandtweiner ${ }^{2}$ \& P. S. Stock ${ }^{3}$ \\ ${ }^{1}$ Department for Management and Economics, \\ Danube University Krems, Austria \\ ${ }^{2}$ Institute of Information Management and Control, \\ Vienna University of Economics and Business, Austria \\ ${ }^{3}$ University of Applied Sciences BFI Vienna, Austria
}

\begin{abstract}
Sustainability reports, as a voluntary measure of companies and organisations, are an important instrument for supporting corporate social responsibility (CSR). The most recognized guidelines for sustainability reporting are the Global Reporting Initiative Guidelines. They aim to enable a reasonable and balanced presentation of a company's performance regarding economic, environmental, and social aspects, to all stakeholders. The paper selects the sustainability reports from four companies from the food industry, two from Europe and two from Latin America. A qualitative analysis highlights to which degree sustainability reporting in Europe and Latin America shows different results.

Keywords: corporate social responsibility, sustainability report, GRI guidelines, food industry, qualitative analysis, Europe, Latin America.
\end{abstract}

\section{Introduction}

One of the most important characteristics regarding the CSR engagement of companies is sustainability reporting. The focus of sustainability reports is on economic, environmental as well as the social impact of the company's activities. A solid foundation of these three fields and of their interaction is the major criteria of a sustainability report.

Due to the globalization of our economy, international frameworks and standards are necessary to enable stakeholders to make sustainable decisions regarding consumption, production and lifestyle. In this context, in 2010 the 
longed for Global Guided Standard for Social Responsibility was published as ISO 26000 [1], and the OECD Guidelines for Multinational Companies [2] were provided. Worldwide around 300 different CSR tools exist. By now some of these tools, standards, codes of ethics and guidelines have become well established. Thus the Sustainability Reporting Guidelines of the Global Reporting Initiative [3] provides recognised guidelines for the measurement, communication and assurance of the companies' economic, environmental and social activities.

On the basis of these guidelines as well as on Stock [4], the authors are able to verify feasible differences between sustainability reporting in Latin America and Europe by a qualitative analysis. From each continent two companies from the food industry were selected for analyses and comparison of their sustainability reports.

\section{Global reporting initiative}

The Global Reporting Initiative (GRI) is a non-profit organization promoting economic, environmental and social sustainability. This project was started by a US non-governmental organisation called CERES in 1997 and in 2000 with the environmental program of the United Nations as a partner, the first GRI Guidelines G1 were presented to the public. Since 2002 GRI has been an independent non-governmental organisation with its seat in Amsterdam. GRI offers a sustainability reporting framework for all companies and organizations.

At present the G3.1 version is available, the GRI Guidelines G4 are expected in the course of 2013. The GRI Sustainability Reporting Guidelines are globally the most recognized ones for sustainability reporting. They were developed with broad stakeholder engagement with the industry, investors and accountants, and are today the most important source for sustainable investments. Currently more than 5000 companies use the GRI Guidelines and it can be observed that the numbers are spiralling upwards. In addition to the general guidelines, GRI offers sector specific supplements, supporting the application of the guidelines in a given sector including sector-specific performance indicators.

\subsection{Sustainability reporting}

The definition of a sustainability report according to the Sustainability Reporting Guidelines is the following: "A sustainability report refers to a single, consolidated disclosure that provides a reasonable and balanced presentation of performance over a fixed time period. Stakeholders should be able to directly access all of the report information from a single location, such as a GRI content index..." [5].

Sustainability reports based on the GRI Reporting Framework are used mainly for the following purposes:

- $\quad$ benchmarking and assessing sustainability of the organization;

- demonstrating the interaction of the organization with sustainable development; 
- comparing performance within an organization for a specific period as well as with other organisations.

The main parts of the GRI Sustainability Reporting Guidelines are first the principles regarding the contents of the report and their quality assurance, secondly the standard disclosures especially concerning performance indicators and thirdly technical aspects of the protocols.

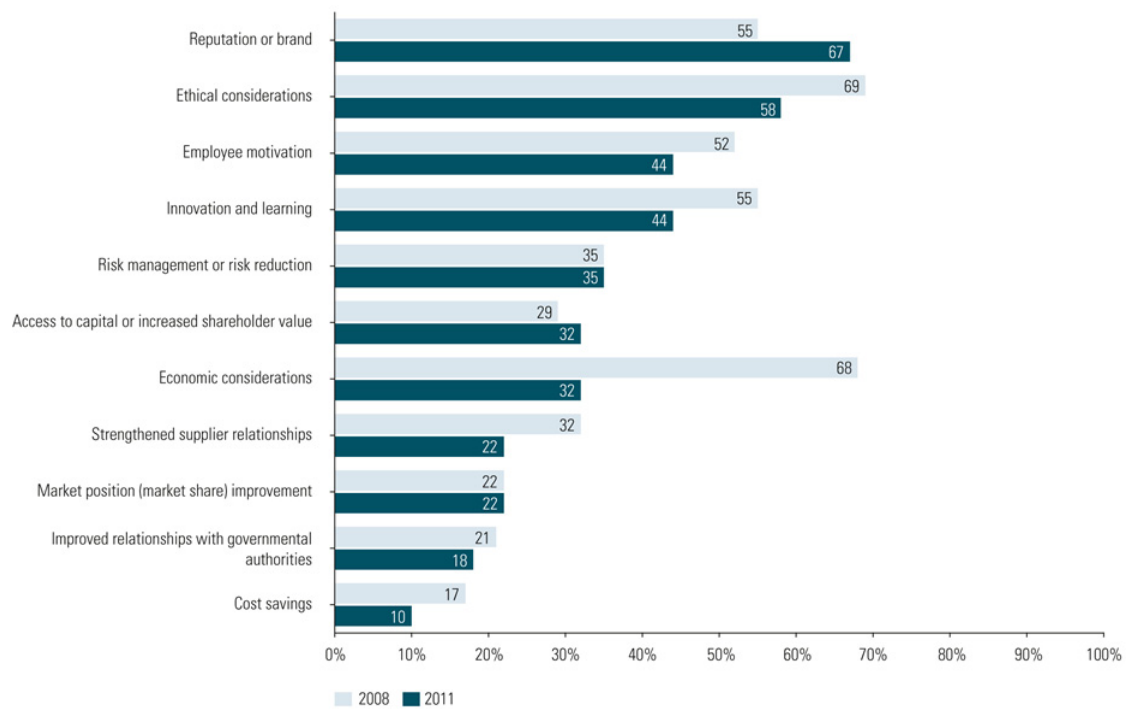

Figure 1: $\quad$ Reasons for G250 companies for CR reporting [6].

The usage of sustainability reports is more common for larger companies than for smaller ones. Companies' grounds for missing reports are mainly the disbelief in positive effects and the huge workload of data collection and reporting. Figure 1 shows the main motivations of the top 250 companies of the Fortune Global 500 list (2010) for providing sustainability reports. Obviously due to the financial crisis the motivations "economic considerations" and "cost savings" have decreased significantly between 2008 and 2011. "Ethical considerations" were ranked first in 2008, but had been relegated to second by "Reputation or brand” in 2011.

Usually sustainability reports are published annually, primarily by companies from developed countries. Figure 2 shows the development of reporting output by continents and demonstrates the leading role of Europe's companies. In recent years reporting has also become more popular in North and Central America as well as Asia. 


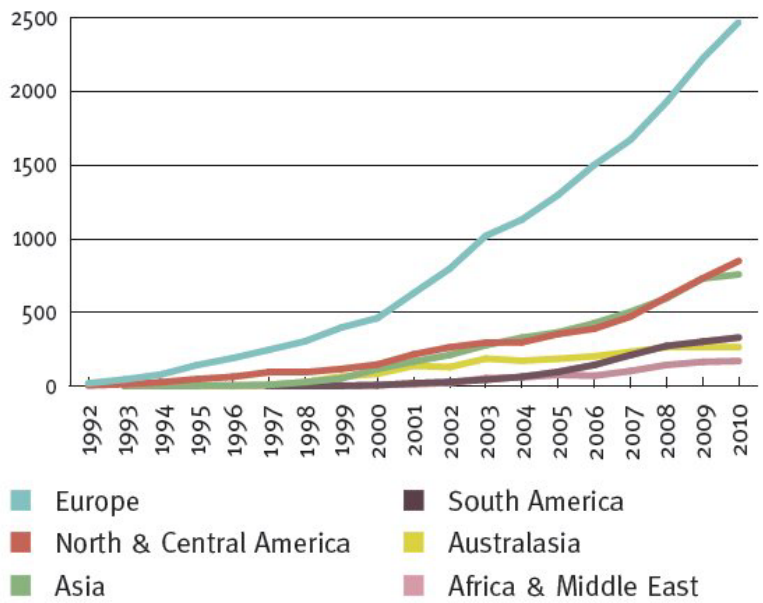

Figure 2: $\quad$ Development of reporting output by region [7].

\subsection{Reporting framework}

Part 1 of the GRI Guidelines refers to the definition of the content, quality and reporting boundary. The principles regarding the content of the report are materiality, stakeholder inclusiveness, sustainability context and completeness. For each principle the guidelines provide a definition, an explanation and a checklist. Additionally, reporting principles for defining qualities like balance, comparability, accuracy, timeless, clarity and reliability, are essential for transparency.

Part 2 provides a description of the main elements of the sustainability report on the basis of part 1: strategy and profile, management approach and performance indicators. The guidelines distinguish between economic, environmental and social performance indicators. The aspects on which the economic indicators focus are economic performance, market presence, and indirect economic impacts. The aspects of the environmental performance indicators are materials, energy, water, biodiversity, emissions, effluents and waste, products and services, compliance, transport, and overall. The social performance indicators focus on labor practices, human rights, society, and product responsibility, with the aspects

- employment, labor/management relations, occupational health and safety, training and education, diversity and equal opportunity, and equal remuneration for women and men for labor practices;

- investment and procurement practices, non-discrimination, freedom of association and collective bargaining, child labor, forced and compulsory labor, security practices, indigenous rights, assessment, and remediation for human rights; 
- local communities, corruption, public policy, anti-competitive behavior, and compliance for society; costumer health and safety, product and service labeling, marketing communications, customer privacy, and compliance for product responsibility.

For strengthening the credibility of their reports, companies have several options. Within the context of the management and reporting processes, internal controls, including internal audits, can be implemented. Additionally GRI recommends external assurance for sustainability reports. For GRI an external assurance requires the publication of its statements regarding the quality of the sustainability report.

After finishing the sustainability report, the organization has to declare according to the "GRI Application Level” system, on which level the GRI reporting framework was applied. This communicates clearly which elements were considered for the preparation of the report. The system offers three levels, titled by C, B and A, with A as the highest level. If external assurance is applied, the organisation can self-declare a plus $(+)$. Around $28 \%$ of the GRI sustainability reports are on level $\mathrm{A}$ or $\mathrm{A}+$, level $\mathrm{B}$ or $\mathrm{B}+$ and $\mathrm{C}$ and $\mathrm{C}+$ each with almost $25 \%$, the balance is undeclared.

\subsection{Growth in the use of the GRI guidelines}

The number of annually published sustainability reports on the basis of the GRI Guidelines shows a huge rise during the last century, nowadays more than 5000 companies use these guidelines. The growth rate was on average $18 \%$ per year. In Europe 50\% of the GRI reports are published, 19\% in North America, 16\% in Asia, 11\% in Latin America, 2\% each in Africa and Oceania [8]. Even though there is a trend for sustainability reporting in all industries, the majority (14\%) of the 2012 GRI reports are out of the financial sector, followed by the energy sector, the energy utilities sector and the food and beverage sector, which accordingly lies fourth in the ranking.

\section{Qualitative analysis of sustainability reports in Europe and Latin America}

This paper investigates and compares sustainability reports through two cases each from Latin America and Europe, in accordance with the GRI Guidelines. The focus is on the European and Latin American food industry. The selected companies from Latin America are situated in emerging economies, the European companies in developed countries. The goal is to identify differences between reports from these two continents, with a focus on diverging priorities and CSR strategies of the single performance indicators.

\subsection{Report selection}

From each of the two continents the authors have chosen one $\mathrm{A}+$ and one $\mathrm{B}$ report from the same industry to guarantee comparability. 
Regarding industries there are structural differences between Europe and Latin America. In Europe most of the sustainability reports are published in the financial sector, however resource intensive industries such as mining and energy have a leading role in Latin America. Due to its huge environmental impact and the availability of sustainability reports for both continents, the food industry has been selected for the qualitative analysis.

For Europe, reports from Austria and Spain are considered, for Latin America, reports from Brazil and Costa Rica. Regarding sustainability reporting, Austria is ranked under the top 10 countries, 42 companies have published a report in 2010. Spain leads the European list in sustainability reporting according to GRI Guidelines, with 167 reports published in 2010. Brazil is the leader in Latin America with 135 reports in 2010, in contrast Costa Rica has only published three reports. Until now there is no country with an obligation for sustainability reporting. Some countries like Austria, Spain, and Brazil are discussing to bind at least listed companies.

The sustainability reports from the food industry are, with 80 to 200 pages, especially extensive. All four selected companies offer the reports to the public via their homepage. Just one report (Bunge, Brazil) is available in English, additionally to the national language. Two out of the four selected reports have external assurance (Heineken, Spain, and Bunge, Brazil). None of the companies had used the sector supplements.

\subsubsection{Heineken, Spain}

Founded in the Netherlands, Heineke is the European market leader and the world's most international brewer. Heineken Spain, with headquarter in Sevilla, is the most important subsidiary of the group. It is one of the leading Spanish companies in the food industry with a turnover of more than one billion euros in 2009. Heineken Spain has published its first sustainability report (Informe de Sostenabilidad 2009, A+) in 2010 [9].

\subsubsection{Die Hoflieferanten biohandels GmbH and Co KG, Austria}

Die Hoflieferanten are an Austrian small-scale enterprise with a turnover of more than 2 million euros. The company produces organic products, runs organic delicatessens and offers home delivery services for organic products. In 2010 Die Hoflieferanten had published their first sustainability report (Nachhaltigkeitsbericht 2010, B) [10].

\subsubsection{Bunge, Brazil}

Bunge Brazil is an international company, which makes business in more than 30 countries around the world. The business segments are trade and processing of agricultural products, the production and sale of fertilizers, and food production. Bunge Brazil, with a turnover of around 3.6 billion euros, publishes its sustainability report (Sustainability in the Value Chain 2010, A+) [11] annually since 2003. 


\subsubsection{Florida Bebidas, Costa Rica}

One of the first companies in Costa Rica which has published its sustainability report, is Florida Bebidas (Reporte de Sostenibilidad 2009, B) [12]. The company produces beer, fruit-based drinks, bottled water, natural fruit drinks, juices, nectars, flavoured alcoholic beverages, and carbonated drinks.

\subsection{Report analysis}

Regarding the reporting quality, there is no significant difference between the four selected companies concerning the company's profile and strategy.

Table 1 shows the performance indicators of the four companies' reports. GRI distinguishes between core indicators and additional indicators, and the former are considered to be important for most of the organisations. Additional indicators have to be used if they are meaningful for the specific company; moreover they are applied by model companies as a special service for particular groups of stakeholders.

Table 1: $\quad$ Performance indicators of the four sustainability reports.

\begin{tabular}{|l|l|l|l|l|}
\hline Level & Company & Country & Indicators & Requirements \\
\hline A + & Bunge & Brazil & $100 \%$ considered & fulfilled \\
\hline A + & Heineken & Spain & $100 \%$ considered & fulfilled \\
\hline B & Florida Bebidas & Costa Rica & $48 \%$ considered $^{1}$ & fulfilled \\
\hline B & Die Hoflieferanten & Austria & $25 \%$ considered $^{2}$ & not fulfilled \\
\hline
\end{tabular}

1 ... between $30 \%$ and $67 \%$ per area.

2 ...between $0 \%$ and $67 \%$ per area.

Heineken's sustainability report impresses by a pleasant presentation and by complete statements regarding profile, strategy and core and additional indicators.

Although the company Die Hoflieferanten offers complete information regarding the profile and strategy statements, it doesn't fulfil the required criteria for level B. This derives from the fact that the report uses 20 core indicators, but from only three out of six areas. Level B asks for at least 20 core indicators with at least one indicator out of each of the six areas: economic, environmental, labor practices and decent work, human rights, society and product responsibility.

The sustainability report of Bunge fulfills level A+ by complete statements regarding profile, strategy and core and additional indicators. It is the one report out of the four selected, which can refer to previous years, because the company started already in 2003 with its first report.

Florida Bebidas fulfils the criteria for level B with complete statements regarding profile and strategy, and $48 \%$ of the indicators.

For a detailed analysis, one performance indicator out of each area is considered specifically. The selection of the six indicators is listed in table 2 . 
Table 2: $\quad$ Selected performance indicators for a detailed analysis.

\begin{tabular}{|l|l|l|}
\hline Indicator & Aspect & Code \\
\hline Economic & Market Presence & EC6 \\
\hline Environmental & Products and Services & EN26 \\
\hline Labor Practices and Decent Work & Occupational Health and Safety & LA8 \\
\hline Human Rights & Child Labor & HR6 \\
\hline Society & Public Policy & SO5 \\
\hline Product Responsibility & Customer Health and Safety & PR1 \\
\hline
\end{tabular}

\subsubsection{Economic performance indicator}

Aspect Market Presence, EC6: policy, practices, and proportion of spending on locally-based suppliers at significant locations of operation.

All four reports consider this indicator. Heineken has 94\% locally-based suppliers, Florida Bebidas 61\%, and Bunge 95\%. The company Die Hoflieferanten doesn't identify a percentage, but mentions that most of the suppliers are regionally. All reports emphasis the importance of locally-based suppliers and the involved feasibility to have an impact on the nearby social environment.

The reports regarding the market presence aspect are similar for local and for global companies.

\subsubsection{Environmental performance indicator}

Aspect Products and Services, EN26: initiatives to mitigate environmental impacts of products and services, and extent of impact mitigation impacts.

Three out of the four selected companies report about this indicator. Die Hoflieferanten emphasis a current monitoring of the electricity consumption. Bunge describes different projects (strict waste separation, information campaigns etc.), aiming more eco-friendly business processes and an increase of the plants' energy efficiency. The company is a partner with a number of some NGOs in carrying out common educational programs for socially and environmentally aware consumption. The main emphasis of Heineken Spain is the reduction of material and packaging. The company is looking continuously for more environmental friendly materials and possibilities to save packaging material. By that Heineken Spain reduced the materials consumed by 3\% per year.

In comparison, the European reports put their measures more in the context with their real business processes, whereas Bunge from Latin America has more diverse projects in mind.

\subsubsection{Labor practices and decent work}

Aspect Occupational Health and Safety, LA8: education, training, counseling, prevention, and risk-control programs in place to assist workforce members, their families, or community members regarding serious.

All four selected companies report about this aspect. Bunge Brazil describes its support and partnerships in some organizations and projects such as information about a sustainable lifestyle including health and a sensitization of 
all parties involved in the supply chain. Florida Bebidas focuses on ergonomics at the workplace, promotion of mental health, further education, and protection from working and environmental noise. By these measures and by a strict meeting of safety regulation, the goal is to eliminate work-related accidents entirely. Similarly, Heineken reports about safety and healthy on all levels and areas of the company. However Die Hoflieferanten emphasis internal and external further education for the employees regarding health, nutrition, and personality.

The reports from Spain, Brazil, and Costa Rica show strong similarity regarding the aspect of occupational health and safety. In contrast Die Hoflieferanten report less extensive and focus solely on further education. Obviously international activity of a company has an impact on this indicator. That confirms also the results of Corporate Register [13], that sustainability reports from Spain and Latin America are the most comprehensive ones.

\subsubsection{Human rights}

Aspect Child Labor, HR6: operations identified as having significant risk for incidents of child labor, and measures taken to contribute to the elimination of child labor.

All companies (except Die Hoflieferanten, which doesn't report about the performance indicators human rights, society, and product responsibility) declare that they haven't any business activities with considerable risk to child labor.

The aspect child labor is treated quite rudimentarily by all companies. Differences in regional characteristics aren't observable, maybe for the reason that the compliance of human rights nowadays is a global standard for reliable companies.

\subsubsection{Society}

Aspect Public Policy, SO5: public policy positions and participation in public policy development and lobbying.

Florida Bebidas follows a codex called „Business Ethics and Behavior“, which considers different aspects such as responsibility for the staff, representation of the company towards costumers and other external groups, confidentialities, conflicts of interests, and punishments. Furthermore it is mentioned that a neutral audit is implemented regarding the compliance of this codex. Heineken Spain reports that it hasn't any political obligations and lobbying activities. Bunge informs about a project for a developing plan for a region in Brazil in collaboration with the local government and the support of a foundation. The Austrian company Die Hoflieferanten doesn't report about this indicator.

The aspect public policy is treated in a very different way by three out of the four companies, so the comparability is limited. The companies from Latin America report more extensively.

\subsubsection{Product responsibility}

Aspect Customer Health and Safety, PR1: life cycle stages in which health and safety impacts of products and services are assessed for improvement, and 
percentage of significant products and services categories subject to such procedures.

All four selected companies inform very extensively about the indicator product responsibility, but Die Hoflieferanten don't report about aspect PR1. Bunge declares to meet all legal conditions and regulations, and that no cases have arisen regarding a breach of the law or an impact on the health of customers. Heineken Spain is ISO 9001 certified and reports extensively about the quality and safety of its products. Florida Bebidas describes this aspect in detail for different business activities regarding health and safety of the costumers, and the labeling of products and services.

The aspect customer health and safety seems to be a very important one for the food industry, therefore the three companies report very detailed about this indicator.

\subsection{Report analysis results}

First national initiatives for obligatory sustainability reporting for large companies have already a positive impact on the increased usage of GRI reports in these specific countries. The focus of the analysis is on different values and on the main emphasis of the single performance indicators between reports from the two selected continents.

The analysis shows that companies doing business locally, report in a different way than multinational companies. The differences are identified on the basis of the general impression of the performance indicators as well as on the qualitative analysis of some selected indicators.

Reports from Latin America are more comprehensive than those from Europe, especially for the level B. Not only the number of included performance indicators is larger, but also the statements for each indicator are more detailed. Different social environments on the two continents cause diverging interpretation. For instance Latin American reports focus more on the indicator LA8 health prevention of the employees and their families. But European companies report additionally about further education in this context. All four reports refer relatively less to the ecological indicators, so they inform rarely about air emissions, sewerage and initiative for energy saving. Some differences could be observed regarding the CSR focusing by means of the indicators PR1 (customer health and safety) and EN26 (products and services). By trend Latin American companies focus more on the compliance of legal regulations, on small projects for reducing environmental impacts as well as on social engagement. European companies' actions are more innovative and concentrate continuously on the process improvement. Independently of the size and the globalization of the company, the performance indicator EC6 (market presence) is used similar on both continents, and locally-based suppliers are of particular importance.

Surprisingly, some performance indicators are used in a very similar way by all companies in spite of cultural and social differences, e.g. the indicator HR6 (child labor). Child labor in Europe is scarcely any issue, but a significant problem in Latin America. The reports don't show this fact, even if the 
companies from Latin America attach more importance to this indicator. All companies exclude child labor categorically. One interpretative attempt is, that a very small number of Latin American companies publishes sustainability reports. These are mostly the leading companies of their country, which often don't represent the actual problems there.

\section{Conclusion}

Corporate social responsibility becomes more important in the social policy debate, especially since the beginning of the financial crises in 2008. Companies and organizations have recognized that sustainable strategies are more and more crucial for their stakeholders and their purchasing decisions.

The paper analyses the contents and differences of sustainability reports from the food industry in Europe and Latin America. Compared to Latin America, the concept of CSR is politically supported in Europe. But in none of the countries is CSR or sustainability reporting an obligation. Several international organisations have developed normative conditions, process guidelines and management systems to support and guide companies in introducing, implementing, and measuring CSR. The Global Reporting Initiative has offered globally recognized guidelines since 2000, which are now used by more than 5000 companies worldwide. The reports serve as a communication tool and enable a dialog with different stakeholder groups. The sustainable activities of a company can be communicated externally and be made transparent and comparable.

The major criticisms about the current concepts of sustainability reporting are the limited verifiability, and that the contents are not evaluated concerning their economic, environmental and social aspects. This means the necessity of an independent evaluation and verification in terms of content.

The qualitative analysis of the four selected companies, two from Europe and two from Latin America, shows differences for the two continents in CSR focusing regarding specific performance indicators, like health prevention, further education or compliance of legal regulations. In general, sustainability reports of Latin American companies are more comprehensive than those of European ones. Furthermore, locally acting companies report in a different way than multinational ones. Just one out of the four analyzed reports is published in English, in addition to the national language, which makes accessing to the information more difficult for some stakeholder groups.

According to the 2020 vision of GRI, the advantages and effects of CSR should be scientifically verifiable, to convince all stakeholders, worldwide recognized report standards and mandatory external verifications should guarantee the reliability and comparability of sustainability reports, consumers should use the information in the reports for their purchasing decisions, and finally in less than 10 years there should be no more necessity for sustainability reports as sustainability aspects should by then be integrated automatically into the company's annual report. Realistically this will be only possible, if the inclusion into company's annual report is mandatory. 


\section{References}

[1] International Organization for Standardization, ISO 26000 Social Responsibility, http://www.iso.org/iso/home/standards/iso26000.htm, 2010.

[2] OECD, OECD Guidelines for Multinational Enterprises, 2011 Edition, OECD Publishing. doi: 10.1787/9789264115415-en, 2011.

[3] Global Reporting Initiative, Sustainability Reporting Guidelines, Version 3.1, https://www.globalreporting.org/resourcelibrary/G3.1-SustainabilityReporting-Guidelines.pdf, 2011.

[4] Stock, P.S., Nachhaltigkeitsberichterstattung in einer globalisierten Welt mit Fokus auf die Global Reporting Initiative - eine Analyse anhand lateinamerikanischer und europäischer Berichte aus der Nahrungsmittelbranche, Master Thesis, Vienna, 2012.

[5] ibid., p.42.

[6] KPMG, KPMG International Survey of Corporate Responsibility Reporting 2011, Publication Number 110973, November 2011.

[7] Corporate Register, The CR Reporting Awards - Global Winners and Reporting Trends, p.4., 2010.

[8] Global Reporting Initiative, Discover the Database, https://www.globalreporting.org/reporting/report-services/sustainability-disclosure-database/ Pages/Discover-the-Database.aspx, 2012.

[9] Heineken España, Sustainability Report 2010, http://heinekenespana.es/ politicas/Informe_Sostenibilidad09.pdf, 2010.

[10] Die Hoflieferanten, Nachhaltigkeitsbericht 2012, http://www.diehoflieferanten.at/01_aktuelle_infos/pdf/nh2010.pdf, 2010.

[11] Bunge, Sustainability Report, Brasil 2010, http://www.bunge.com.br/ sustentabilidade/2010/en/index.html, 2010.

[12] Florida Bebidas, Reporte de Sostenibilidad 2009, http://www.florida.co.cr/ docs/responsabilidad_social/reporte_sostenibilidad_2009.pdf, 2010.

[13] Corporate Register, CR Reporting Awards. Global Winners and Reporting Trends. http://www.corporateregister.com/pdf/CRRA07.pdf, 2008. 